\begin{tabular}{c|l|l|l|l}
\hline Volume 2 & Issue 2 & August (2021) & DOI: 10.47540/ijsei.v2i2.270 & Page: $188-195$ \\
\hline
\end{tabular}

\title{
Contribution of Forestry in Economy and Employment Generation in Nepal
}

\author{
Yamuna Paudel ${ }^{1}$, Ashish Paudel ${ }^{2}$ \\ ${ }^{1,2}$ Faculty of Forestry, Agriculture and Forestry University, Hetauda, Nepal \\ Corresponding Author: Yamuna Paudel; Email: yamunapaudel29@gmail.com
}

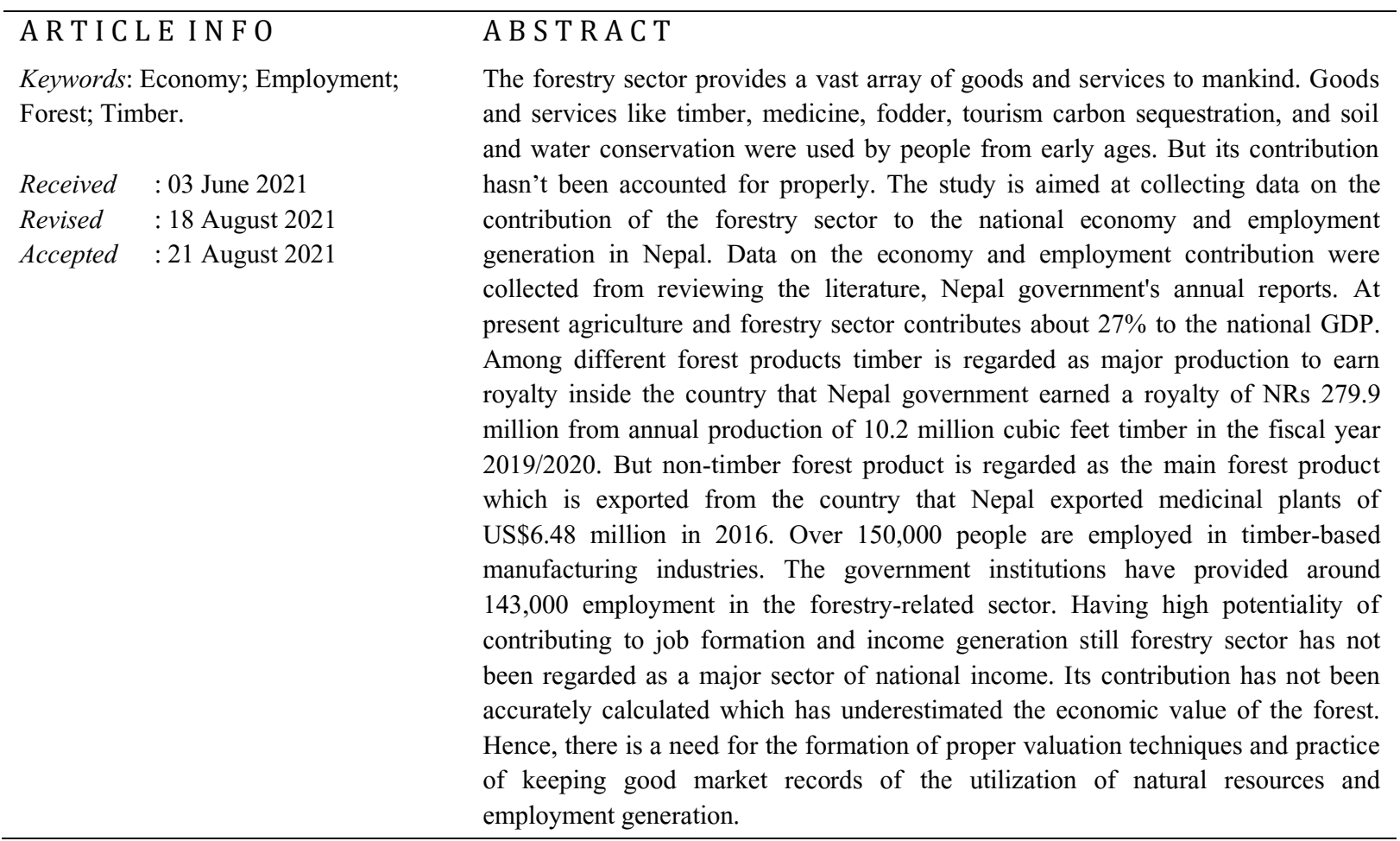

\section{INTRODUCTION}

Forest resources are vital sources of income, livelihoods, and wellbeing for the rural population. About 1.6 billion (over $25 \%$ ) population of the world is dependent on forest areas for livelihood, employment, and income source. Of which about 1 billion are extremely poor partly and 300-350 million poor totally depend on forest resources for their subsistence (Chao, 2012). People with a poor economy are found to be involved more in the utilization of forest resources. In Nepal, about 44.74 $\%$ of the forest area has diverse economic potential and about $60 \%$ of people directly depend on forest resources (Kanel, 2007; Basyant et.al, 2020; FRTC, 2019). More than one-third forest of Nepal is handed over to local communities user groups as a community-based forest regime that benefits over 2.9 million households by direct involvement of them in benefit sharing and decision-making mechanisms (MoF, 2020a). Timber is regarded as a major source of government revenue inside the country. For better management of forest and sustainable production of timber, the government has formed different management regimes like community forest, collaborative forest, private forest, which are the major sources of timber inside the country (MoF, 2020). Of total timber produced from different management regimes, the private sector singly covers $86.6 \%$ which makes it the highest timber-producing regime. It is mainly managed by private agencies or people which proves that timbers are not only the main income source of government but also is a backbone of private forest. Likewise, the government-managed forest produces $7.7 \%$ and the community forest produces $5.5 \%$ of timber (Meilby et al., 2014). 
From all these forest management systems government earned a royalty of NRs. 279.9 million in the fiscal year (2019/2020). And also income earned from Community forests is used in forest management, community development, employment generation, and capacity building of poor and women but still there exists unemployment, poverty, and food insecurity because of weak social safety nets in developing countries (Lund et al., 2014; Baral et al., 2019; FAO, 2020).

Likewise, the collection and sale of Nontimber forest products (NTFPs) are a significant livelihood diversification for the marginalized family-supporting remarkably in their household incomes (Melaku et al., 2014; Ros Tonen, 2000). Their dependency on these products largely increases during the period of hardships as they act as a safety net for them (Anderson et.al, 2006). These products have been the sources for medicines, nutrition, and other values as well along with the income-generating measure. The emerging concept of Sustainable development and its targets like poverty reduction, food security, and medicinal herbs for health has increased the interest of the world towards NTFPs as their multiple roles in improving human livelihood and sustainable development have been recognized. Millions of people are dependent on NTFPs at a global level that only in India over 50 million depend on NTFPs to overcome their basic needs (Shaanker et al., 2004). The contribution of NTFPs to rural people and forest dwellers in the context of Nepal is also remarkably noticeable. Certain reports have highlighted their economic contribution to rural livelihood. Still, there is very little information and scientific records of the economic contribution of forest resources in Nepal (Subedi, 2006). However, some micro-level studies have been carried out on the economic contribution of overall forest products. There is no separate record for the contribution of non-timber forest products. The forestry sector is considered highly supportive in contributing to the national GDP through trade. But there is no proper enumeration of economic benefits that arise from various goods and services of forest (Maharjan, \& Dangal, 2020). Also, environmental services provided from the forest ecosystem contribute to both the national economy and income generation to local people but they remain unpaid or free-ridden (Huang \& Upadhyaya, 2007).

Forest goods and services contribute significantly to national income and employment. However, it is not calculated accurately as it is calculated in combination with agriculture which always underestimates the value of forest products. This study aims to find out the contribution of forest goods and services to the economy and employment generation in Nepal.

\section{Materials AND MeTHODS}

The study was conducted in Nepal which is located between latitudes $26^{\circ} 22^{\prime}$ and $30^{\circ} 27^{\prime} \mathrm{N}$ and longitude $80^{\circ} 40^{\prime}$ and $88^{\circ} 12^{\prime}$ 'east. Nepal lies on the southern slope of the central Himalayas with an average length of $885 \mathrm{~km}$ and a width of $193 \mathrm{~km}$. It is a topographically diverse country that lies in latitudinal variation from $57 \mathrm{~m}$ to $8848 \mathrm{~m}$ from sea level.

The study involves an extensive literature review based on methods used by other researchers (Bandaje, 12; Bhatt, 2011; Maharjan and Dangal, 2020). We used the Google scholars, Scopus for reviewing papers (eg: Anderson et.al, 2006; Basyant et.al, 2020). And most of the data are collected from Nepal government publications and its annual progress reports (eg: DoF, 2013; DoF; 2018; MoFE, 2015). For study government reports from 2015 were focused on finding the latest contribution of the forestry sector in national income and employment (eg: Fiscal yearbooks 2013, 2017/18, 2018/19). Likewise, some information was collected from organizations' documents like FAO, World Bank, Multi-stakeholder forestry program documents.

The study focused on the government royalty collection as primary data on forestry sector contribution to the economy through different forest management practices and protected areas, and the forestry sector is grouped into timber product, NTFP, ecosystem services (Carbon, Tourism, Zoos, etc.) and their role is identified on employment generation through enterprise, forest management activities, tourism jobs, government sector employment under forestry sector, etc. 


\section{RESULTS AND DISCUSSION Forestry sector contribution to national GDP}

Forest goods and services play a vital role in economic development, poverty reduction, employment generation, improving livelihood, and overall national GDP. However, a detailed study on the contribution of the forestry sector to the national GDP has not yet been carried out separately, but it is calculated combine with agriculture under the broad heading of Agriculture and forestry. Different agencies had estimated different figures on the contribution of the forestry sector to national GDP. National planning commission estimated $39.3 \%$ contribution to GDP in Ninth Five-year Plan (19972002) (NPC, 2002), 34.9\% in Tenth Five-Year Plan (2002-2007) (NPC, 2007). Likewise, FAO estimated $3.5 \%$ contribution in 2000 and $4.4 \%$ for the period of 1990 to 2000 (FAO, 2004). And the ministry of finance estimated a $27.6 \%$ contribution to GDP in 2017/2018 AD (MoF, 2018).

\section{Forest products contribution to the national economy}

Forest resources provide both direct and indirect benefits to the national economy. Direct benefits include the provision of goods such as timber, NTFPs, firewood, fibers with opportunities for jobs and income generation from harvesting and value chain addition. Likewise, good forest management and conservation provide various ecosystem services and contribute indirectly to economic sectors such as agriculture (nutrition, biomass for fertility), the energy sector (fuels wood, sedimentation control around hydropower dams), tourism (flora and fauna), and transport (that is, erosion control) (World Bank, 2018). The forestry sector's different agencies collected 1 Arab 75 crore 42 lakh royalty in 2073/74 and 2 Arab 47 crore royalty in 2074/2075 (MoFE, 2015) which is shown in table 1 . The table shows two years of royalty collection data of different agencies of the Ministry of forest and environment and from the table, we can understand the increasing trend of forest resources on royalty contribution and economy that DOFSC had collected $1,43,99,89,361$ in 2074/75 (2014/15 AD) which is higher than $1,06,75,74,506$ Nepali Rupees year 2073/2074 (2013/14 AD). The royalties collected in table 1 covers the income from taxes, exports, internal marketing of timber and NTFP as well as from tourism services, vats, etc.

Table 1 . Royalty collecting agencies and royalties in 2 fiscal years

\begin{tabular}{|l|l|l|}
\hline Forest agency & Royalty $(073 / 74)$ & Royalty $(074 / 75)$ \\
\hline Department of forest and soil conservation & $1,06,75,74,506$ & $1,43,99,89,361$ \\
\hline Department of National Park and wildlife conservation & $55,27,36,503.3$ & $70,58,87,000$ \\
\hline Department of plant resources & $1,63,50,781$ & $1,80,31,445$ \\
\hline Forest research and training center & 62765.7 & 8,580 \\
\hline Forest product development board & $4,31,27,092$ & $22,71,66,000$ \\
\hline Timber co-operation Nepal & $5,64,35,000$ & $27,77,63,659$ \\
\hline Total & $1,75,42,01,168$ & $2,47,10,57,481$ \\
\hline
\end{tabular}

Source: MOFE, 2015

\section{Contribution of timber products to the economy}

In Nepal, forest products like timber and fuelwood are the important sources of income of the government, community forestry user groups as well as poor rural people. Using timber and fuelwood and exporting timber (in Rana regime railway slippers were exported to India) has remained an important part of revenue collection throughout the modern history of Nepal. Timber production and utilization continues to grow in recent years. Timber products shared over $90 \%$ of the revenue of the total forestry sector in 2008/2009 (Banjade, 2012). Likewise, selling wood products contributed about $90 \%$ of the annual income of different community forest user groups in Nawalparasi district in 2010 (Bhattarai, 2011) which shows timber is the most significant product of community forest in Nepal (Pokhrel, 2006). Also, the government's plantation projects like Sagarnath forestry project and Ratuwamai forest project have collected about 5 crores 79 lakh royalties from the sale of timber products (MOFE, 2015). From the selling of timber alone from the governmentmanaged forest, the government earned about 375.7 Nepali Rupees (NRs.), and community-managed forest user groups earned Rs. 341.3 million through community-based forest management which is as shown in table 2 . 
Table 2. Timber revenue

\begin{tabular}{|c|c|}
\hline Item & $\begin{array}{c}2018 / 2019 \text { (Rs. In } \\
\text { million) }\end{array}$ \\
\hline Government revenue & 375.7 \\
\hline Forest User Group income & 341.3 \\
\hline
\end{tabular}

Source: DoF, 2018

\section{Contribution of Non-Timber forest products in economy}

NTFPs have contributed to rural livelihood and the national economy as well. NTFPs are used as sources of food, medicine, sources of fiber, and flosses which makes them major exporting forest product in Nepal that about 10,000 to 15,000 tons of NTFP products of more than 100 species were exported to India annually in 1996 whereas about 12,000 tons of NTFP were traded in 2012 (Edwards, 1996; DoF, 2013). At present, about 161 NTFP species are commercially traded in Nepal (Subedi, 2006). The study from eastern Nepal reported an average annual income of Rs 12,000 from the sale Swertia chirayita (Edwards, 1996). Likewise, another study from Gorkha district reported that NTFP collection commonly provides $15-35 \%$ of the annual income of poor households in the northern and middle parts of the district (Olsen, 1998). But still, there is not accurate reporting of the economic value and contribution of NTFP to the national economy.

In the fiscal year 2005/06, the NTFP trade generated NRs.67.38 million as revenue which contributed $14 \%$ of total forestry sector income (MoF, 2006; DoF, 2007b). Nepal exports Medicinal and Aromatic Plants (MAPs) of value worth US $\$ 6.48$ million in 2016 which made the country the $49^{\text {th }}$ largest exporter of MAPs (Mckenna, 2018). NTFP is not only a government source of revenue but also the source of annual household income of 10 to $100 \%$ mountainous population (Pyakurel \& Oli, 2012). NTFP exports and trade in market areas are recorded by the government but they don't cover the total trade value of NTFP because man NTFPs are traded as informal transactions and the record-keeping system is poor (Kanel, 1999).

\section{Contribution of forest services to the economy}

Forest services like tourism, carbon trade, and environmental services also contribute to the economy but they are at an early stage of development in Nepal. Nepal has a total forest carbon pool of about 920 million $\mathrm{tCO}_{2} \mathrm{e}$ which sequester about 55 million $\mathrm{tCO}_{2} \mathrm{e}$ annually (Subedi \& Singh, 2008) which indicates the huge potentiality of Nepal's forest to earn from carbon trade. Nepal has the potentiality of selling about 8.25 million tCO2e per annum under a conservative scenario and 19.5 million $\mathrm{tCO}_{2} \mathrm{e}$ under an optimistic scenario (Subedi et.al, 2014). Likewise, protected areas, community forest has highly contributed in tourism development in Nepal that more than 800,000 tourists visited Nepal in 2012. At present, about $60 \%$ of tourists visiting Nepal visit protected areas and benefit approximately 1 million 142 thousand people living near protected areas.

In 2017/2018 about 349 thousand tourists visited conservation areas by contributing Rs. 35 million revenue, 382 thousand domestic and external tourists visited National Botanical Garden contributing Rs. 14.2 million as revenue (MoF, 2017; MoF, 2018). Likewise, in 2019/2020 NRs. 37 crore 83 lakh royalty has been collected through tourism in Protected areas through the visit of about Five lakh five hundred thirty-seven tourists. World Travel and Tourism Council has projected $1,318,000$ tourists will visit Nepal in 2023 (WTTC, 2012).

\section{Contribution of forestry in employment}

The forestry sector is broad and combines different subsectors and also it is divided into different agencies which create direct and indirect employment. A study by the MSFP (2014a) estimates that in a conservative scenario, the forest sector can provide up to 420,000 jobs. At present different forest management regimes are creating employment opportunities in Nepal that the private sector provides nearly 99,000 formal full-time jobs, community forestry user groups (CFUGs) provide about 31,000 jobs. Likewise, Tilaurakot collaborative forest has contributed to creating an annual job for more than 20 thousand man-days on average that was equivalent to more than 56 thousand US\$ to the date (Pathak, 2017). The forestry sector has formed different enterprise, cooperatives which directly provides loans, jobs to poor. The Tamakoshi Bel Juice Processing Company in collaboration with the user's group had given various opportunities to the poor by employing a partial to full-time basis in fruit collection and processing, providing wages and productivity bonuses (Paudel, 2005). Likewise, forest-based industries can generate over 400,000 
sustainable, full-time jobs which can go up to 1.38 million depending upon the performance (Subedi et.al, 2014).

The timber based-based industries have employed over 150,000 persons through manufacturing industries (Bhatta, 2011). In the fiscal year 2019/2020, 2,004 forest-based small and cottage industries were formed and in 2020/21, 768 forest-based industries are promoted which contributed to forming 73 lakh working days in

Table 3. Scenarios for Potential Economic Value and Employment Opportunities of Forest Subsectors

\begin{tabular}{|l|l|l|l|l|}
\hline \multirow{1}{*}{ Subsector } & $\begin{array}{c}\text { Economic value } \\
\text { (NPR, millions) }\end{array}$ & \multirow{2}{*}{$\begin{array}{c}\text { Full-time jobs } \\
\text { (NPR, millions) }\end{array}$} & \multicolumn{1}{|c|}{$\begin{array}{c}\text { Optimistic } \\
\text { Scenario }\end{array}$} \\
\cline { 2 - 4 } & $\begin{array}{c}\text { Conservative } \\
\text { Scenario }\end{array}$ & Optimistic scenario & $\begin{array}{c}\text { Conservative } \\
\text { Scenario }\end{array}$ & \\
\hline Timber & 55,127 & 270,997 & 206,725 & 812,090 \\
\hline NTFP & 11635 & 58,173 & 87,259 & 290,865 \\
\hline Carbon & 4235 & 13,572 & 37,054 & 118,755 \\
\hline Ecotourism & 14572 & 21,567 & 72,860 & 107,883 \\
\hline Forest bioenergy & 2,126 & 9,107 & 15,633 & 53,571 \\
\hline Total & 87,695 & 373,116 & 419,531 & $1,383,114$ \\
\hline
\end{tabular}

Source: World Bank, 2018

Likewise, the Ministry of Forest and Environment (MOFE) and its agencies have conducted different programs and provided about

one lakh forty-three thousand four hundred thirty employment opportunities (MoFE, 2015) which are shown in table 4.

Table 4. employment opportunities provided by different agencies

\begin{tabular}{|l|l|l|}
\hline Agency & Workdays & Full-time job \\
\hline Department of forest and soil conservation & $3,57,00,000$ & $1,34,210.53$ \\
\hline Department of plant resources & 37,064 & 139.34 \\
\hline Department of National parks and Wildlife conservation & 4,67262 & $1,576.62$ \\
\hline Forest research and training center & 16,684 & 25.59 \\
\hline President chure conservation & $14,86,971$ & $5,590.12$ \\
\hline Forest product development program & 132,700 & 498.87 \\
\hline Timber corporation Nepal & 70,510 & 265.08 \\
\hline Herbs production and processing company & $2,33,696$ & 878.56 \\
\hline Regional and central research centre & 982 & 3.69 \\
\hline Total & $3,81,52,639$ & $1,43,430.97$ \\
\hline
\end{tabular}

Source: MOFE, 2015

Among different agencies, the Department of forest and soil conservation contributed the highest full-time employment and working days. And Regional and Central Research Centre and Forest research and training center have comparatively less contribution in employment generation. This result showed that forest research agencies have less contribution on the job so there is a necessity to focus on forest research.
2019/2020 and 17 lakh 49 thousand working days in 2020/2021 respectively (MoF, 2021). World Bank estimated about 419,531 million full-time jobs in the conservative scenario and 1,383,114 million in an optimistic scenario which is as shown in table 3 . Among various forest goods and services, timber and NTFP have high income and employment opportunities possibility in both conservative and optimistic scenarios. 
Forestry but its exact contribution on GDP is always underestimated as it is counted combined with agriculture. Timber products play a major role in earning royalty inside the country whereas NTFP is mostly exported products that earn foreign revenue. Valuation of forest services like Tourism, Carbon trade, PES is only in starting phase in Nepal. Proper implementation of such a mechanism can create a huge contribution to the national economy. Forest management regimes like community forest, collaborative forest, private forest, forest-based enterprises, protected areas, the tourism sector have contributed to forming employment opportunities in the forestry sector. Also, government organizations like Ministries, Departments, research agencies, NGOs have contributed to the formation of job opportunities in the forestry sector of Nepal.

\section{REFERENCES}

Anderson, J., Benjamin, C., Campbell, B., \& Tiveau, D. (2006). Forests, poverty and equity in Africa: New perspectives on policy and practice. International Forestry Review, 8, 44-53.

Banjade, M. (2012). Discourse and Discursive Practices over Timber in Nepal. Journal of Forest and Livelihood, 10(1): 58-73.

Baral, S., Chhetri, B. B. K., Baral, H., \& Vacik, H. (2019). Investments in different taxonomies of goods: What should Nepal's community forest user groups prioritize?. Forest policy and economics, 100, 24-32.

Basnyat, B., Baral, S., Tiwari, K. R., Shrestha, G. K., Adhikari, B., \& Dahal, Y. N. (2020). Covid-19 Outbreak, Timber Production, and Livelihoods in Nepal. Tribhuvan University Journal, 15-32.

Bhatta, S. (2011). Timber Worth Two Billion Unattended. Nagarik Daily. Kathmandu, Nepal Republic Media.

Bhattarai, R. C. (2011). Economic impact of community forestry in Nepal: a case of midhill districts of Nepal. Economic Journal of Development Issues, 75-96.

Chao, S. (2012). Forest peoples: Numbers across the world. Forest People Program, United Kingdom. Council, London.

Department of Forest. (2007b). Hamro Ban. Department of Forests, Kathmandu, Nepal.
Department of Forest. (2012). Hamro Ban. Department of Forests, Ministry of Forests and Soil Conservation, Government of Nepal.

Department of Forest. (2013). Hamro Ban. Department of Forests, Ministry of Forests and Soil Conservation, Government of Nepal.

Department of Forest. (2018). Annual Report, 2017/2018. Department of Forest. Nepal.

Department of Forest. (2018). Annual Report, 2017/2018. Nepal. Department of Forest.

Edwards, D. M. (1996). Non-timber forest products from Nepal. FORESC Monograph 1/96.

FAO. (2020). The impacts of COVID-19 on the forest sector: How to respond?. Food and Agriculture Organizations of the United Nations (FAO). FAO, Italy, Rome.

Forest Research and Training Centre. (2019). An Assessment of Nepal's Forestry Sector's Contribution to Sustainable Development Goals (SDGs), Forest Research and Training Centre (FRTC), Ministry of Forests and Environment, Kathmandu, Nepal.

HMGN. (2000). Forestry Sector Policy 2000. Ministry of Forests and Soil Conservation, Government of Nepal.

Huang, M., \& Upadhyaya, S. K. (2007). Watershedbased payment for environmental services in Asia.

Kanel, K. R. (1999). Policy related issues in nontimber forest products business. Non timber Forest Produces: Production, Collection and Trade of NTFPS in Mid-Western Development Region of Nepal, Kathmandu: HMG, USAID, BSP and New ERAl.

Kanel, K. R. (2007). Economic impacts of forest policy changes: A perspective from Nepal. The Initiation, 1, 36-42.

Lund, J. F., Baral, K., Bhandari, N. S., Chhetri, B. B. K., Larsen, H. O., Nielsen, Ø. J., \& Treue, T. (2014). Who benefits from taxation of forest products in Nepal's community forests?. Forest Policy and Economics, 38, 119-125.

Maharjan, S., \& Dangal, M. R. (2020). Economic Contribution of Non-Timber Forest Products in Rural Livelihood of Dolakha, Nepal. Open Journal for Research in Economics, 3(2). 
Mckenna, J. M. (2018). Medicinal and Aromatic Plants. The World Bank. (No. 134294, pp. 1-61).

Meilby, H., Smith-Hall, C., Byg, A., Larsen, H. O., Nielsen, Ø. J., Puri, L., \& Rayamajhi, S. (2014). Are forest incomes sustainable? Firewood and timber extraction and productivity in community managed forests in Nepal. World Development, 64, S113S124.

Melaku, E., Ewnetu, Z., \& Teketay, D. (2014). Non-timber forest products and household incomes in Bonga forest area, southwestern Ethiopia. Journal of forestry research, 25(1), 215-223.

MoF. (2020a). Economic survey: Fiscal year 2019/2020. Ministry of Finance, Nepal. https://mof.gov.np/uploads/document/file/ Economic_Survey_2076-77.pdf.

Ministry of Finance. (2020a). Economic survey: Fiscal year 2019/2020. Ministry of Finance, Nepal..https://mof.gov.np/uploads/document/ file/ Economic_Survey_2076-77.pdf.

Ministry of Finance. (2006). Economic Survey 2005/06. Ministry of Finance, Kathmandu, Nepal.

Ministry of Finance. (2017/2018). Fiscal year book 2017/18. Ministry of Finance, Kathmandu, Nepal.

Ministry of Finance. (2018/19). Fiscal year book 2018/2019. Ministry of Finance, Kathmandu, Nepal.

Ministry of Finance. (2019/2020). Fiscal year book 2019/2020. Ministry of Finance, Kathmandu, Nepal.

Ministry of Forest and Environment. (2015). Annual report 2074/2075. Ministry of Forest and Environment, Nepal.

MSFP (Multi Stakeholder Forestry Program). (2014a). Potential of Forestry Sector in Economic Growth and Development: Short Concept Notes on five themes. Kathmandu, Nepal.

National Planning Commission. (2007). Approach Paper to the Eleventh Interim Plan (20072010). National Planning commission Nepal.

National Planning Commission. (2002). The Tenth Plan (2002-2007). National Planning Commission Secretariat, Nepal.
Olsen, C. S. (1998). The trade in medicinal and aromatic plants from central Nepal to northern India. Economic Botany, 52(3), 279-292.

Pathak, B. R. (2017). Comprehensive contributions and sustainability of collaborative forest Management Practice: A Case study from TILAURAKOT collaborative forest Management, Nepal.

Paudel, D. (2005). Including the excluded: A propoor Bel fruit juice making enterprise in Nepal. International Tropical Timber Organization (ITTO), Community Forestry Training Center for Asia and the Pacific (RECOFTC), Forest Trends, RRI, Thailand, 10-19.

Pokharel, B. K., Paudel, D., \& Gurung, B. D. (2006). Forests, community-based governance and livelihoods: Insights from the Nepal Swiss Community Forestry Project. Capitalization and Sharing of Experiences on the Interaction between Forest Policies and Land Use Patterns in Asia: Linking people with resources, 53-60.

Pokhrel, R. A. (2004). Asia-Pacific Forestry Sector Outlook Study (No. 25). FAO Working Paper Series.

Pyakurel, D., \& Oli, B. R. (2012). NTFPs/MAPs business promotion strategy (2012-2016), from private sector perspective. FNCCIAEC/NEHHPA, Kathmandu, Nepal.

Ros-Tonen, M. A. (2000). The role of non-timber forest products in sustainable tropical forest management. Holz als roh-und Werkstoff, 58(3), 196-201.

Shaanker, R. U., Ganeshaiah, K. N., Krishnan, S., Ramya, R., Meera, C., Aravind, N. A., ... \& Reddy, B. C. (2004). Livelihood gains and ecological costs of non-timber forest product dependence: assessing the roles of dependence, ecological knowledge and market structure in three contrasting human and ecological settings in south India. Environmental Conservation, 242-253.

Subedi, B. P. (2006). Linking plant-based enterprises and local communities to biodiversity conservation in Nepal Himalaya. Akhil Book Distributors. 
Subedi, B. P., \& Singh, S. P. (2008). Ecosystem services in Nepal and Uttarkhand Himalayas: a few observations based on pilot study.

Subedi, B. P., Ghimire, P. L., Koontz, A., Khanal, S. C., Katwal, P., Sthapit, K. R., \& Mishra, S. K. (2014). Private Sector Involvement and Investment in Nepal's Forestry Sector: Status, Prospects and Ways Forward. Multi Stakeholder Forestry Programme.

WTTC. (2013).Travel and Tourism Economic Impact 2012: Nepal. World Travel and Tourism Center.

World Bank. (2018). Country Forest Note: Nepal. C World Bank. 